\title{
Impact Of Microcredit Programs On Higher Income Borrowers: Evidence From Bangladesh
}

Sayma Rahman, University of Western Sydney, Australia

Rafiqul Bhuyan Rafiq, California State University, San Bernardino, USA

Mohammad A. Momen, University of Dhaka, Bangladesh

\begin{abstract}
In this study, we investigate the impact of microcredit on economic indicators of borrowers in Bangladesh and compare if the impact is same across borrowers having different income levels. Our estimation results show that the microcredit programs are effective in generating higher income and assets for borrowers in general. However, the impact is not found to be uniform across income levels of borrowers. Higher income borrowers seem to be better off compared to the middle and lower income borrowers. It is also observed that the age and education of the household head and his/her partner in the family are significant and make a better impact of the household.
\end{abstract}

Keywords: Microcredit, Household Indicators, Poverty.

\section{INTRODUCTION}

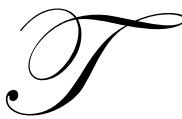

he success of microcredit programs in Bangladesh has brought international attention to this unique model and received widespread application in other developing countries. It is a unique innovation of a credit delivery technique to enhance income generating activities that is a collateral-free groupbased lending strategy (Hulme and Mosley, 1996; Yunus, 1999; World Bank, 1994). It is perhaps the most sensational anti-poverty tool for the poorest, especially for women who have ever been given a loan for the first time in any country in the world. Microcredit in Bangladesh has drawn attention of researchers throughout the world because of its distinctive credit delivery system, high recovery rate and its special focus on women. The impact of microcredit on poverty alleviation is so far found to be controversial, however. Several studies have found that the microcredit program has a positive impact on eradicating poverty (Hossain, 1988; Khandker, 1998; Wahid, 1993; Yaron, 1994) but other studies, for example Morduch (2000), Weiss and Montgomery (2005), report a negative impact. To substantiate such a controversy, it is important to assess the impact of microcredit programs on economic and/or household indicators of the borrowers. In doing so, first, it is necessary to identify factors that are essential measures/indicators of poverty second, to find out whether these factors are ultimately affected by these microcredit programs and finally, to compare the impact across borrowers with different income-levels. In this study, we have investigated the impact of microcredit on household indicators following Pitt and Khandker (1998). In addition, we have divided the borrowers into three groups based on their income level to assess the impact on borrowers from different income groups. The rest of the paper is structured as follows: Section 2 provides the background literature; Section 3 describes the data and its sources; Section 4 specifies the model, and the results are discussed in Section 5. A conclusion is drawn in the final section.

\section{DATA AND METHODOLOGY}

In this study we used primary data collected through a structured questionnaire from borrowers of two major microcredit institutions in Bangladesh such as the Grameen Bank and the BRAC. These two large institutions 
have coverage all over the country. Based on different agro-climatic and socio-economic conditions, we have selected three districts of Bangladesh to collect data. The districts are Gazipur, Dinajpur and Chokoria. Gazipur is close to Dhaka, the capital city, and Dinajpur and Chokoria are chosen from the far northern and southern parts of the country for different socio-economic effects. From each districts five villages are chosen at random. The borrowers were selected in a cluster from each village. The samples of borrowers were randomly selected without replacement from the list of households available in each villagae's local office. Randomness and socio-economic and cultural backgrounds were used as control variables to facilitate a better comparison. From all three districts 387 borrowers were interviewed through a structured questionnaire.

The primary focus of this study is to estimate the impact of microcredit on various household outcomes, such as income and assets from two major microcredit institutions in Bangladesh, viz., the Grameen Bank and BRAC. To analyze the impact of microcredit using data from borrowers of the above mentioned institutions, we have adopted the model suggested by Pitt and Khandker (1998). Pitt and Khandker (1998) consider the credit $\mathrm{C}_{i j}$ (endogenous variable) depends on some household characteristics, some villages specific characteristics and on some other variables. So the model used by them is:

$$
C_{i j}=\alpha+\beta_{c} X_{i j}+\gamma_{c} V_{i j}+\pi Z_{i j}+\varepsilon_{i j}{ }^{C}
$$

Where $X_{i j}$ is the vector of exogenous household characteristics (e.g., some demographic factors of the household), $V_{i j}$ is the vector of village characteristics (community infrastructure), $\mathrm{Z}_{i j}$ is also a vector of a set of household or village characteristics which are different from the $\mathrm{X}$ 's and V's in that they affect $\mathrm{C}_{i j} \cdot \beta_{c}, \gamma_{c}$ and $\pi$ are unknown parameters, and $\varepsilon_{i j}{ }^{c}$ is a random error composed of three components

$$
\varepsilon_{i j}^{c}=\eta_{j}+\mu_{j}+e_{i j}^{c}
$$

Where $\eta_{j}$ and $\mu_{j}$ are unobservable household-specific and village-specific effect respectively, and $e_{i j}{ }^{c}$ is a nonsystematic error uncorrelated with the other error components or the regressors. According to Pitt and Khandker (1998), the household outcome $Y_{i j}$ (we have used 'income', and 'assets' whereas Pitt and Khandker have used 'savings' alone) depends on amount of $\mathrm{C}_{i j}$ as well, which may be explained as:

$Y_{i j}=\beta_{y} X_{i j}+\gamma_{y} V_{j}+\delta C_{i j}+\varepsilon_{i j}^{y}$

Where $\beta_{y}, \gamma_{y}$ and $\delta$ are unknown parameters and $\varepsilon_{i j}{ }^{y}$ is the error term. Models containing simultaneous equations are estimated through instrumental variables in general. However, maximum likelihood estimates could also be a possible alternative, which provides efficient results. In this study we have used 2SLS (2 stage least square) to estimate the above mentioned simultaneous equations model.

\section{RESULTS AND DISCUSSION}

Table 1 shows that coefficient of total expenditure (income) is significant and positive. This implies that incomes of the households are affected positively by the amount of credit. As amount of credit increases, expenditure (income) of the households also increase. Age of the female, as well as male, is found significant and positive. That tells us that as age of both male and female increases, income of the household also increases. To see the effect of age, we have further estimated the equation using age-squared. We have found negative and significant coefficient of age-squared for both male and female. This implies that as age increases, income of the household 
increases; but after a certain level, it starts dropping. This is a realistic finding as in real life people's income increases as they grow older but falls after a certain level when they stop working.

Table 1

2SLS Estimation of Amount of Borrowing on Household Outcome: Log of Total Expenditure/Income

\begin{tabular}{|l|c|c|}
\hline \multicolumn{1}{|c|}{ Explanatory Variables } & Lquation 1 & Equation 2 \\
\hline Constant & $4.35^{* * *}(2.58)$ & $3.72^{* * *}(2.12)$ \\
\hline Log of Amount of Borrowing & $0.95^{* * *}(3.74)$ & $1.94 * * *(3.66)$ \\
\hline Age of the Female & $0.56^{* *}(2.07)$ & - \\
\hline Age-squared (female) & $-0.28^{* * *}(-2.58)$ & - \\
\hline Education of the Female & $0.38^{*}(1.82)$ & $0.55^{* *}(2.06)$ \\
\hline Age of the Male & - & $-0.46^{* * *}(-2.78)$ \\
\hline Age-squared (male) & - & $0.22^{* *}(2.28)$ \\
\hline Education of the Male & - & $0.29 * * *(3.41)$ \\
\hline Gender of the Household Head & $0.31^{* * *(3.87)}$ & $-0.001(-0.71)$ \\
\hline Number of Males as a Percentage of & $-0.001 \quad(-0.73)$ & $0.04(0.39)$ \\
Family Size & $0.01(0.12)$ & $-0.008(-0.16)$ \\
\hline Village has Electricity & $-0.03 \quad(-0.62)$ & 0.14 \\
\hline Village has Paved Roads & 0.25 & $22.14(0.0000)$ \\
\hline$R^{2}$ & $23.33 \quad(0.0000)$ & 387 \\
\hline $\begin{array}{l}\text { F-statistic (8,379) } \\
\text { Prob. }>\text { F }\end{array}$ & 387 & \\
\hline Number of Observations & & \\
\hline
\end{tabular}

(***) significant at $1 \%$ level, $(* *)$ significant at $5 \%$ level, $(*)$ significant at $10 \%$ level and figures in the parentheses show the $\mathrm{t}-$ values using White corrected standard errors.

Table 1 also shows a positive coefficient for education of both male and female. That means education has a positive role in providing higher income for the households. The coefficient of education for female and male is found significant at 5\% and 10\% levels respectively. In our sample, most of the households are male-headed. Our estimation results from Table 1 suggest that the male-headed households have a larger expenditure (income) for the family.

Table 2 shows the 2SLS estimation results of the simultaneous equations model. It shows that the microcredit program affects household assets significantly and positively. The positive coefficient of assets implies that as credit increases, assets of the households also increase. This could be interpreted as one of the achievements of microcredit programs. Table 2 also shows a positive and significant coefficient for age of the male and female. That means as the age of the male increases, household assets also increase. We also could conclude that education contributes to better quality of life through enhancing household assets for both male and female. Education enlightens everyone and plays an important role in bringing better assets for the households. Our results suggest that the microcredit programs are successful in improving the quality of life of borrowers through accumulation of assets and income. These results are consistent with the findings of Pitt and Khandker (1998).

Since we have found a positive impact of microcredit on household outcomes, now we want to see how this impact varies among different income level borrowers. We divided the borrowers into three equal groups according to their income levels. Each group contains $33.33 \%$ borrowers and are classified as high, middle and low income groups. As we know, $94 \%$ of microcredit borrowers are female and at the same time, there is a high correlation between age and education of males and females. We therefore decided to focus only on female age and education in the following estimations. 
Table 2

2SLS Estimation of Amount of Borrowing on Household Outcome: Log of Assets

\begin{tabular}{|c|c|c|}
\hline Explanatory Variables & \multicolumn{2}{|c|}{ Log of Assets } \\
\hline & Equation 1 & Equation 2 \\
\hline Constant & $-3.72 * *(-2.12)$ & $-7.37 *(-1.68)$ \\
\hline Log of Amount of Borrowing & $1.41 * * *(2.72)$ & $1.51 * * *(2.74)$ \\
\hline Age of the Female & $0.01 * *(2.05)$ & - \\
\hline Education of the Female & $0.02 * *(2.28)$ & - \\
\hline Age of the Male & - & $0.56 * *(2.07)$ \\
\hline Education of the Male & - & $0.04 * *(2.67)$ \\
\hline Gender of the Household Head & $0.41 *(1.72)$ & $0.48 *(1.69)$ \\
\hline $\begin{array}{l}\text { Number of Males as a Percentage of } \\
\text { Family Size }\end{array}$ & $0.003(0.52)$ & $0.003(0.54)$ \\
\hline Village has Electricity & $0.56 * *(2.07)$ & $0.48(1.69)$ \\
\hline Village has Paved Roads & $-0.12(-0.90)$ & $-0.07(-0.52)$ \\
\hline$R^{2}$ & 0.16 & 0.17 \\
\hline $\begin{array}{l}\text { F-statistic }(7,379) \\
\text { Prob. }>\text { F }\end{array}$ & $25.52(0.0000)$ & $22.29(0.0000)$ \\
\hline Number of Observations & 387 & 387 \\
\hline
\end{tabular}

(***) significant at $1 \%$ level, $(* *)$ significant at $5 \%$ level, $(*)$ significant at $10 \%$ level and figures in the parentheses show the t-values using White corrected standard errors.

Tables 3 and 4 show the 2SLS estimation of the effects of microcredit programs on household outcomes (total expenditure and assets) based on different income level borrowers. The findings of Tables 3 and 4 are very interesting. We found positive and significant coefficient of income for high income level borrowers. For middle income level borrowers, income is positive but significant at the $10 \%$ level. The table also shows that the age of the female is positive and significant across all income levels. Table 3 further shows that as age increases, income of the households increases for all income level borrowers. Education of the female is positive and significant at the $10 \%$ level for high and middle income level borrowers. Male-headed households provide better income for high and low income level households. From Table 3 we found that having electricity in the village increases income for the low income level borrowers.

Table 4 shows the results of the impact of microcredit on household assets on different income level borrowers. It is interesting to see from the significant and positive coefficient that as amount of borrowing increases, assets increase only for the higher income level borrowers. The coefficient is positive and significant at $10 \%$ level for the middle income level borrowers. Age of the female is positive and significant across all income level borrowers. This implies that as the age of the female increases, households possess more assets. However, as education of the female increases household assets increase for higher income level borrowers only. Households with more adult males provide better assets across all income groups. Having electricity in the village increases assets only for the higher income level borrowers.

Our findings in Tables 3 and 4 suggest that the high income group of borrowers is better off compared to middle and low income group borrowers. We therefore accept the null hypothesis that the high income group is better off compared to the low and middle income groups. The tables further show that as the amount of credit increases, income and assets of high income group borrowers increase. This is interesting to see as education of the female increases, household assets increase only for the higher income level borrowers. Electricity in the village expedites income for the low income level borrowers only. 
Table 3

2SLS Estimation of Amount of Borrowing on Different Income Level Borrowers: Log of Total Expenditure

\begin{tabular}{|c|c|c|c|}
\hline Explanatory Variables & $\begin{array}{c}\text { High Income Level } \\
\text { Borrowers } \\
\end{array}$ & $\begin{array}{c}\text { Middle Income Level } \\
\text { Borrowers }\end{array}$ & $\begin{array}{c}\text { Low Income Level } \\
\text { Borrowers }\end{array}$ \\
\hline Constant & $5.00 * * *(3.69)$ & $6.69 * * *(3.99)$ & $5.31 * * *(2.94)$ \\
\hline $\begin{array}{l}\text { Log of Amount of } \\
\text { Borrowing }\end{array}$ & $0.455 * * *(2.86)$ & $0.12 *(1.68)$ & $0.23(1.17)$ \\
\hline Age of the Female & $0.01 * *(2.56)$ & $0.13 * * *(3.11)$ & $0.3 * * *(3.21)$ \\
\hline Education of the Female & $0.024 *(1.90)$ & $0.01 *(1.86)$ & $0.01(0.08)$ \\
\hline $\begin{array}{l}\text { Gender of the Household } \\
\text { Head }\end{array}$ & $0.33 * *(2.23)$ & $0.04(0.50)$ & $0.32 * *(2.54)$ \\
\hline $\begin{array}{l}\text { Male as Percentage of } \\
\text { Family Size }\end{array}$ & $-0.004(-1.17)$ & $-0.001(-0.55)$ & $-0.001(-0.39)$ \\
\hline Village has Electricity & $0.001(0.01)$ & $0.07(1.24)$ & $0.59 * * *(3.71)$ \\
\hline Village has Paved Roads & $-0.11(-0.88)$ & $-0.06(-0.82)$ & $-0.02(0.27)$ \\
\hline$R^{2}$ & .25 & .29 & .27 \\
\hline $\begin{array}{l}\text { F-statistic }(7,121) \\
\text { Prob. > F }\end{array}$ & $\begin{array}{c}23.22 \\
0.0000\end{array}$ & $\begin{array}{c}24.31 \\
0.0000 \\
\end{array}$ & $\begin{array}{c}23.21 \\
0.0000 \\
\end{array}$ \\
\hline Number of observations & 129 & 129 & 129 \\
\hline
\end{tabular}

(***) significant at $1 \%$ level, $(* *)$ significant at 5\% level, $(*)$ significant at $10 \%$ level and figures in the parentheses show the t-values using White corrected standard errors.

Table 4

2SLS Estimation of Amount of Borrowing on Different Income Level Borrowers: Log of Assets

\begin{tabular}{|c|c|c|c|}
\hline Explanatory Variables & $\begin{array}{c}\text { High Income Level } \\
\text { Borrowers }\end{array}$ & $\begin{array}{c}\text { Middle Income Level } \\
\text { Borrowers }\end{array}$ & $\begin{array}{c}\text { Low Income Level } \\
\text { Borrowers }\end{array}$ \\
\hline Constant & $6.60 * * *(4.28)$ & $5.31 * * *(3.60)$ & $4.35 * * *(2.58)$ \\
\hline Log of Borrowing & $1.69 * * *(2.85)$ & $0.12 *(1.68)$ & $1.99(1.30)$ \\
\hline Age of the Female & $0.18 * * *(3.17)$ & $0.01 * *(2.40)$ & $0.02 * * *(2.40))$ \\
\hline Education of Female & $0.003 * * *(2.58)$ & $0.19(1.21)$ & $0.001(1.09)$ \\
\hline Gender of House Head & $-0.16(-1.42)$ & $-0.65(-1.09)$ & $-0.18(-1.07)$ \\
\hline Male as $\%$ of Family & $0.008 * * *(2.89)$ & $0.18 * *(2.58)$ & $0.33 * *(2.23)$ \\
\hline Village has Electricity & $0.03 * *(2.00)$ & $0.18(1.07)$ & $0.008(0.81)$ \\
\hline Village(Paved Roads) & $-0.20(-1.49)$ & $-0.001(0.05)$ & $-0.12(-0.72)$ \\
\hline$R^{2}$ & .21 & .26 & .31 \\
\hline $\begin{array}{l}\text { F-statistic }(7,121) \\
\text { Prob. > F }\end{array}$ & $20.68(0.0000)$ & $23.99(0.0000)$ & $21.19(0.0000)$ \\
\hline No. observations & 129 & 129 & 129 \\
\hline
\end{tabular}

$(* * *)$ significant at $1 \%$ level, $(* *)$ significant at 5\% level, $(*)$ significant at $10 \%$ level and figures in the parentheses show the t-values using White corrected standard errors.

\section{CONCLUSION}

In this research, we analyze the impact of microcredit on household outcomes, such as income and assets, using a modified form of the model suggested by Pitt and Khandker (1996) by assessing the impact of microcredit separately on household expenditure (income) and assets. We further differentiated the impact of credit on different income level borrowers. In addition, we have also used some refined and log transformed variables to estimate the model compared to previous studies. Our findings suggest that the microcredit programs are effective in generating higher income and assets for borrowers. Our results also suggest that: 1) age of the female, as well as the male, has a significant and positive impact on income and assets; 2) someone's income increases as the person grows older, but income starts to decline after a certain level when they stop working; 3 ) education of the female, as well as the male, is an important factor in affecting income and assets positively; 4) as the number of earners increases in a 
household, the amount of borrowing also increases; and finally, 5) microcredit programs help yield better outcomes for high income group borrowers compared to medium and low income group borrowers.

Overall, this study suggests that even though microcredit is an attractive tool for producing better outcomes in terms of income and assets, it is more effective for relatively wealthier borrowers compared to non-wealthy borrowers. A good research project in the future would be to determine why this is the case. At the same time, our results suggest that there should be some adjustment to the existing microcredit programs to achieve the intended outcome; that is, to serve the purpose of those in the lower income society.

\section{AUTHOR INFORMATION}

Dr. Sayma Rahman is a lecturer at Yanbu University College, Saudi Arabia. Prior to joining there, she was adjunct faculty at University of Technology, Sydney, Australia, and Full time faculty at University of Dhaka, Bangladesh. Dr. Rahman received her PhD from University of Western Sydney, Australia.

Dr. Rafiqul Bhuyan Rafiq is an Associate Professor of Finance at California State University, San Bernardino, USA. Dr. Rafiq served several north American university and published numerous articles in various international journals. Dr. Rafiq received his PhD from Concordia University, Montreal, Canada.

Mr. Momen is an Associate professor of finance at University of Dhaka Bangladesh where he served over 12 years. Mr. Momen received his MBA from Indiana University, USA.

\section{REFERENCES}

1. Hossain, M. 1988, Credit for Alleviation of Rural Poverty: The Grameen Bank in Bangladesh, International Food Policy Research Institute, Washington, D.C.

2. Hulme, D. and Mosley P. 1996, Finance against poverty, London, Routledge Int. Publishing Company.

3. Hussain, A. M. 1998, Poverty Alleviation and Empowerment: The Second Impact Assessment Study of BRAC's Rural Development Programme, BRAC, Dhaka.

4. Khandker, S.R. 1998 Fighting Poverty with Microcredit, Oxford University Press, Washington, D.C.

5. Morduch, J. 1999, 'The Microfinance Promise', Journal of Economic Literature, vol. 37, no. 4, pp. 1569-

1614.

6. Morduch, J. 2000, 'The Microfinance Schism’, World Development, vol. 28 no. 4, pp. 617-29.

7. Pitt, M. and Khandker, S. 1998, 'The Impact of Group-Based Credit Programmes on Poor Households in Bangladesh: Does Gender of the participant Matter?’ Journal of Political Economy vol. 106, pp. 958-996.

8. Wahid, N.W. 1993, The Grameen Bank Poverty Relief in Bangladesh, West View Press.

9. Weiss, J. and Montgomery, H. 2005, 'Great Expectations: Microfinance and Poverty Reduction in Asia and Latin America', Oxford Development Studies, vol. 33, no. 3 and 4, pp. 391-416.

10. World Bank, 1994, 'The World Bank's Strategy for Reducing Poverty and Hunger, Environmentally Sustainable Development Studies', Monograph series, vol. 4, no. 3.

11. Yaron, J. 1994, 'What Makes Rural Finance Institute Successful?' The World Bank Research Observer, vol. 9, no 1, pp. 49-70

12. Yunus, M. 1999, Banker to the Poor, The Autobiography of Muhammad Yunus, Founder of the Grameen Bank, Aurun Press Ltd. London.

13. Yunus, M. 1983, 'Group -based Savings and Credit for the Rural Poor: Grameen Bank in Bangladesh. Group-based Savings and Credit for the Rural Poor', Papers and Proceedings of a workshop, Bogra (Bangladesh), Geneva: ILO. 